\title{
THE INFLUENCE OF AGRICULTURAL HOLDINGS ON THE DEVELOPMENT OF RURAL AREAS
}

\author{
Natalia Demianenko, Hanlar Makhmudov, Tatyana Schetinina \\ Poltava State Agrarian Academy, Ukraine
}

\begin{abstract}
The paper deals with the effect of concentration of agricultural holdings of farmland on the development of rural areas. The analysis of this problem has revealed a number of problems of social and environmental nature. Sustainable tendency to increase the concentration holdings of farmland does not have a proper positive impact on the development of rural areas. It has been noted that there are no effective mechanisms of influence on agricultural holdings of public authorities and local governments. The situation of increasing the area of agricultural land of farms of Myrhorod district of Poltava oblast, within the vertically-integrated companies has been studied. The mechanism of agricultural holdings' involvement in territorial cluster to establish the cooperation on the implementation of social, economic, and environmental community projects has been proposed. It has proved the necessity of the consolidation of social responsibilities of agricultural holdings to support rural communities at the legislative level, where the companies use farm land for their work.
\end{abstract}

Keywords: agricultural holdings, land-use, concentration of farmland, rural areas, sustainable development, development program, social infrastructure, community support

DOI: 10.17512/znpcz.2016.1.09

\section{The statement of the problem}

The development of rural areas largely depends on the activities of local agricultural enterprises. Considering the fact that in recent years, more and more farmers are joining vertically integrated companies, it is advisable to consider the impact of agricultural holdings on the development of rural areas. They concentrate a considerable part of land and funds available for investment. At the present stage agricultural holdings in Ukraine rapidly increase the volume of agricultural production and meet the demand of domestic and foreign agricultural markets of the country. However, their activities do not make for the development and social well-being of rural areas. Therefore, we consider it relevant to study the correlation between the concentration of agricultural holdings of agricultural land and rural development.

\section{The analysis of recent studies and publications}

The issue of the formation and activities of agricultural holdings in Ukraine is the subject of thorough scientific studies of the economists (I. Lukinov, P. Sabluk, S. Demianenko, V. Andriychuk, V. Boiko, V. Vasylenko, A. Dankevych, O. Krysalnyi, A. Mazur, M. Malik, Y. Nesterchuk, O. Onyshchenko, V. Tereshchenko, 
G. Cherevko, V. Yurchyshyn and V. Yatsenko). The scientists pertinently note that in recent years agricultural holdings take the form of "economics in economy» (Кропивко, Лупенко 2013, pp. 5-21; Brzozowska, Kalinichenko, Kabus 2015, pp. 10-14). The growing influence of the holding companies in the agricultural sector of Ukraine encourages the scientific community to in-depth studies of various aspects of this trend.

An important direction of research studies is the analysis of the impact of agricultural holdings on the state of rural areas.

The objective of the paper is to study the impact of the concentration of agricultural holdings of farmland on rural development in Ukraine.

\section{The main material research}

Nowadays the decline of rural areas is one of the most acute social and economic problems in Ukraine. Since the independence in 1991, special attention has been paid to the issues of social and economic revival of the rural areas in each legislative acts dealing with the development of agriculture and the economy of the state as a whole. The concepts, strategies and development programs to improve economic and social living standards in rural areas are developed by the efforts of public authorities and research institutions at different levels of management. Despite considerable efforts and funds spent on rural development, the system results are not significant. There was a gap between agriculture, from a purely economic point of view, and rural areas that were historically and are linked to agriculture, - on social and ecological sides (Шанін 2015, pp. 189-194).

It should be mentioned that the reform of land relations in Ukraine over the last decades has been largely aimed at supporting village.

Scientists quite rightly point out «that small farm business with the lack of reliable channels of material supply and final products marketing and in light of not having sufficient financial resources for the modernization of production equipment and innovation cannot compete with other agricultural producers, including foreign ones» (Шувар, Підгребельна 2015, pp. 58-64).

In contrast, large integrated associations have impressive economic results agricultural holdings, the actual influence on the living standards and well-being of rural areas is not significant.

The Law of Ukraine «On holding companies in Ukraine» regulates the formation and development of agricultural holdings. Article 1 of the Law states that holding company is a joint-stock company that owns, uses and disposes of holding corporate shareholding (parts, shares) of two or more corporate enterprises. N. Zarytska points out that «the leading way of their [agricultural holdings] formation ... has been the infusion of domestic and foreign capital in non-agricultural processing industry and the subsequent marketing, for the purpose of self-sufficiency in raw materials, development of agriculture» (Зарицька 2010, p. 312)

The appearance of holding companies in agricultural sector of Ukraine has caused a problem of concentration of agricultural lands by one entity. This 
situation has significantly affected the prospects for the development of rural areas and has showed the new context of studies of agricultural holdings to wide scientific public and managers.

In particular, P. Kulinich is considering the sale of tenant rights on agricultural land. The author points out that «powerful offensive of agricultural holdings is happening in terms of the moratorium on sale of agricultural land, using the tenant right» and stresses that «all the farm tenure of agricultural holdings is based on lease contract of farm lands» (Кулініч 2014). The researcher concludes that agricultural holdings have a negative influence on the development of the market turnover of agricultural lands and the formation of the farm sector of agricultural production.

O. Volovyk also comes to such critical conclusions about the negative effects of agricultural holdings on the development of land relations. The scientist says that «since 2004, a large-scale concentration of land-use has begun and manifested in increasing the area of leased land, formation of new agricultural holdings, vertically and horizontal by integrated structures, are as of tens, hundreds of thousands of hectares of land. The concentration has monopolized the benefits of international trade in farm products and foodstuffs» (Воловик 2012, p. 4).

The analysis of agricultural holdings as a business entity in the agricultural sector gives the author the opportunity to emphasize their negative impact on rural development: «By skillfully using tax advantages and preferences provided by the legislation for agriculture, these economic structures appropriate the costs to be a source of full reproduction of the used natural and social resources in rural areas and improving the quality of life of the local environment, but actually «washed out» from the village».

Nowadays there is the indisputable fact that agricultural holdings, using the mechanisms of mergers and acquisitions of agricultural enterprises of the traditional type, have increased the size of landuse. The concentration of agricultural holdings of farmland took place regardless of whether enterprises were limited liability companies or private companies or turned into organizational departments of new companies.

In 20145,85 million hectares or nearly $28 \%$ of all farmland were under the control of agricultural holdings, which are in use of agricultural enterprises. In comparison with the last year, the total land bank of holdings has been down by 0,19 million ha. However, the land-use share has increased from $27,4 \%$ to $27,9 \%$ (figure1) because of exclusion of agricultural land of Crimea from the calculations. In general, the annexation of Crimea has coursed the total land bank of holdings' reduction by at least 125 thousand ha (Найбільші агрохолдинги України [Електронний ресурс]: веб-сайт агропорталу AgriSurver - Режим доступу: https://docviewer.yandex.ua)

The trend towards increasing the concentration of agricultural land is confirmed in the analysis of data from the ten largest Ukrainian agro-enterprises over the period of 2012-2014 (table. 1). The agricultural holding UkrLandFarming occupies a leading position, which has increased by 162 thous. ha $(31,9 \%)$ the size of farmland in 2014, compared to 2012. The company «Kernel Group» for the same 
period has increased their land bank by 75 thous. ha or 22,7\%. PJSC «Myronivskyi Hliboproduct» has increased in 2014, compared to 2012, the size of farmland by 40 thous. ha or $14,3 \%$. The size of farmland, concentrated by other agricultural holdings, remained almost unchanged over the period 2012-2014 (on February 5, 2015, the company New Century Holding (NCH) went on record increasing its land bank by 30 thous. ha (Агропросперис (NSH) / Агропортал Latifundist.com [Електронний ресурс] - Режим доступу: http://atifundist.com/rating/top100/ 27938-new-century-holding)).

mln. ha

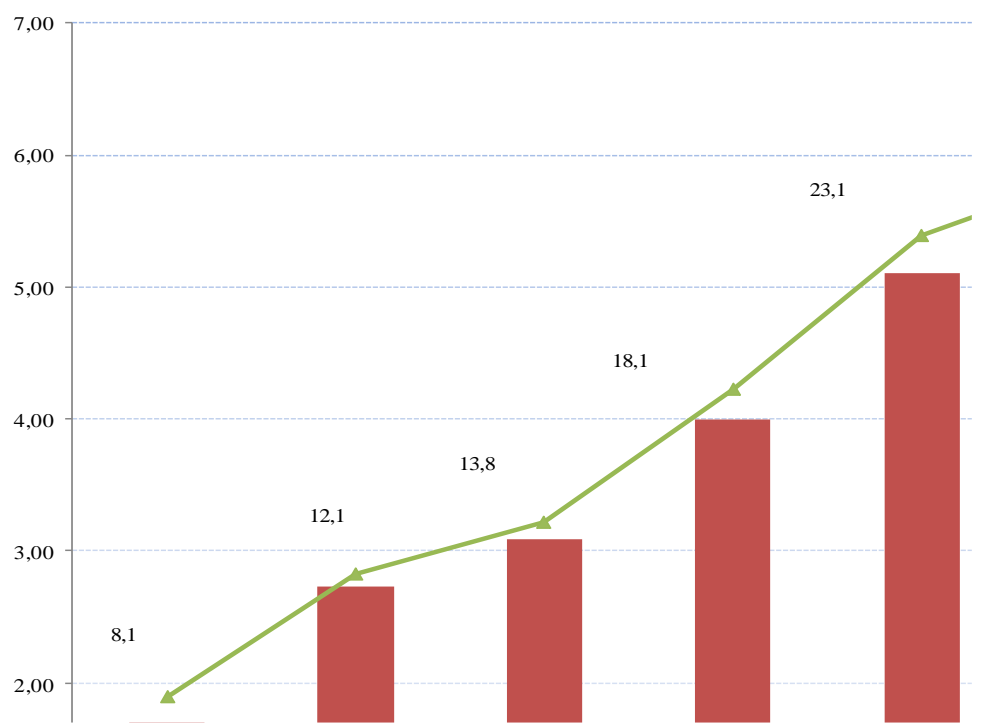

Figure 1. Land Bank of agricultural holdings of Ukraine, 2007-2014

Source: Worked out by authors on the basis of: Найбільші агрохолдинги України [Електрон ний ресурс]: веб-сайт агропорталу AgriSurver - Режим доступу: https://docviewer. yandex.ua.

The analysis of the concentration of agricultural holdings of farmland on the territorial component is significant too. The agricultural holding «UkrLandFarming» occupies again a leading position, which cultivates farmland in 23 oblasts (administrative districts) of Ukraine (most land under the control of the company is located in Poltava and Sumy oblasts - more than 50 thous. ha as a detailed map of the agricultural holding assets informs on its official website (Ukrlandfarming. Publik Limited Company: Офіційний сайт [Електронний ресурс] - Режим доступу: http://www.ulf.com.ua/ru)). PJSC «Mriya» takes the second place, occupying 16 oblasts. Then we can also note the company New Century Holding (NCH) (13 oblasts) and Kernel Grupp (11 oblasts) (table. 1).

The analysis of the data presented in table 1 , shows that the priority farmland for agricultural holdings is of Poltava and Kharkiv oblasts, where 6 out of 10 companies have their land banks. There is farmland in Ternopil, Sumy, Kharkiv 
and Khmelnytskyi, managed by 5 out of 10 agricultural holdings. The Land of Vinnytsia, Chernihiv and Chernivtsi oblasts attracted interests of 4 out of 10 agricultural companies.

Thus, Ukrainian agricultural holdings over the period 2012-2014 continued the trend towards the concentration of farmland. In addition, these companies have showed the greatest active attitude to the formation of their own land banks in the districts with fertile black soil.

Table 1. The dynamics of the size of farmland used by the largest agricultural enterprises in Ukraine (as on January 1, 2012-2014.), thous. ha

\begin{tabular}{|c|c|c|c|c|c|}
\hline \multirow{2}{*}{$\begin{array}{c}\text { The name of } \\
\text { the agricultural } \\
\text { holding }\end{array}$} & \multicolumn{3}{|c|}{ Years } & \multirow{2}{*}{$\begin{array}{l}2014 \\
\text { from } \\
2012, \\
(+,-)\end{array}$} & \multirow{2}{*}{$\begin{array}{c}\text { Oblasts (administrative districts), } \\
\text { where land of agricultural } \\
\text { holdings is located }\end{array}$} \\
\hline & 2012 & 2013 & 2014 & & \\
\hline UkrLand-Farming & 508 & 532 & 670 & 162 & 23 oblasts of Ukraine \\
\hline Kernel Grupp & 330 & 330 & 405 & 75 & $\begin{array}{l}\text { Ternopil, Odesa, Mikolayiv, } \\
\text { Kirovohrad, Cherkasy, Poltava, Sumy, } \\
\text { Chernihiv, Kharkiv, Dnipropetrovsk, } \\
\text { Khmelnitskyi }\end{array}$ \\
\hline $\begin{array}{l}\text { New Century } \\
\text { Holding }(\mathrm{NCH})\end{array}$ & - & 400 & 400 & $\mathrm{x}$ & $\begin{array}{l}\text { Sumy, Chernihiv, Kharkiv, Poltava, } \\
\text { Mykolayiv, Vinnitsa, Chernivtsi, } \\
\text { Zhytomyr, Khmelnytskyi, Ternopil, } \\
\text { Rivne, Volyn, Lviv }\end{array}$ \\
\hline $\begin{array}{l}\text { Myronivkyi } \\
\text { Hliboproduct }\end{array}$ & 280 & 280 & 320 & 40 & $\begin{array}{l}\text { Kiev, Cherkasy, Poltava, Sumy, } \\
\text { Dnipropetrovsk, Donetsk, Kherson, } \\
\text { Vinnytsia and Ivano-Frankivsk }\end{array}$ \\
\hline Mriya & 295 & 295 & 298 & 3 & $\begin{array}{l}\text { In } 16 \text { oblasts of Ukraine (the largest } \\
\text { area of farmland - in Chernihiv, } \\
\text { Kirovohrad, Sumy, Poltava and } \\
\text { Chernivtsi) }\end{array}$ \\
\hline $\begin{array}{l}\text { Ukrainian } \\
\text { Agrarian } \\
\text { Investments }\end{array}$ & - & 260 & 261 & $\mathrm{x}$ & $\begin{array}{l}\text { Ternopil, Khmelnytskyi, Ivano- } \\
\text { Frankivsk, Chernivtsi, Lviv }\end{array}$ \\
\hline Astarta-Kyiv & 245 & 220 & 245 & 0 & $\begin{array}{l}\text { Poltava, Kharkiv, Vinnytsia, } \\
\text { Khmelnytskyi, Ternopil and Zhytomyr }\end{array}$ \\
\hline HarvEast & 220 & 220 & 197 & -23 & Donetsk \\
\hline Agroton & 170 & 171 & 151 & -19 & Luhansk and Kharkiv \\
\hline Sintal Agricultur & 150 & 150 & 150 & 0 & Kharkiv and Kherson \\
\hline
\end{tabular}

Source: Топ 100 латифундистов Украины [Електронний ресурс]: веб-сайт агропорталу

Latifundist.com - Режим доступу : http://latifundist.com.

V. Urkevych says that «agricultural holdings provide the concentration of land by forcing a certain number of agricultural enterprises and farmers out the letting land market, exacerbating social and economic situation in rural areas. Its main features are: the loss of farms in certain area; decline in employment in rural areas; lack of tax revenues to local budgets; lack of funding of development of rural infrastructure, traditionally carried out by agricultural enterprises» (Уркевич 2014). 
Agricultural holdings are active tenants of farmland on a large scale all over Ukraine, including Myrhorod district of Poltava oblast.

A number of agricultural enterprises located here are included into the structures of agricultural holding companies, including: LLC «Promin-Pryvat» and LLC «Savyntsi» that belong to the famous corporation «Pryvat-Agro»; LLC «UkrLatAgro», that is a part of the agricultural holding, whose parent company is located in the Republic of Latvia; LLC «Agrotech-Garantiya», that cultivates over 16 thous. ha of land.

Now we are going to analyze the farmland size distribution of existing farms of Myrhorod district of Poltava oblast (table 2), that will be a criterion dividing the enterprises into groups: «small performers», «followers», «average performers», «sub-leaders», «leaders» [criteria development - author N. Demianenko].

Table 2. The farmland size distribution of farms of Myrhorod district of Poltava oblast 2009, 2014

\begin{tabular}{|c|c|c|c|c|c|c|c|c|}
\hline \multirow{2}{*}{$\begin{array}{l}\text { Groups of } \\
\text { enterprises of } \\
\text { agricultural } \\
\text { area land, ha }\end{array}$} & \multicolumn{2}{|c|}{$\begin{array}{l}\text { Number of } \\
\text { enterprises }\end{array}$} & \multicolumn{2}{|c|}{$\begin{array}{c}\text { In } \% \text { of the total } \\
\text { number }\end{array}$} & \multicolumn{2}{|c|}{$\begin{array}{c}\text { Area of } \\
\text { farmland } \\
1 \text { company, ha }\end{array}$} & \multicolumn{2}{|c|}{$\begin{array}{l}\text { Area farmland } \\
\text { of total area, \% }\end{array}$} \\
\hline & 2009 & 2014 & 2009 & 2014 & 2009 & 2014 & 2009 & 2014 \\
\hline $\begin{array}{l}\text { Small } \\
\text { performers }- \text { to } \\
1000 \text { ha }\end{array}$ & $\mathrm{x}$ & 6 & $\mathrm{x}$ & 30,0 & $x$ & 437,7 & 0 & 3,6 \\
\hline $\begin{array}{l}\text { Followers - } \\
\text { from } 1001 \text { to } \\
3000 \text { ha }\end{array}$ & 7 & 3 & 50,0 & 15,0 & 1731,3 & 1411,5 & 21,0 & 5,8 \\
\hline $\begin{array}{l}\text { Average } \\
\text { performers - } \\
\text { from } 3001 \text { to } \\
5000 \text { ha } \\
\end{array}$ & 3 & 5 & 21,4 & 25,0 & 3874,9 & 3775,5 & 20,2 & 25,9 \\
\hline $\begin{array}{l}\text { Sub-leaders - } \\
\text { from } 5001 \\
\text { to10000 ha }\end{array}$ & 2 & 5 & 14,3 & 25,0 & 5416,6 & 6175,0 & 18,8 & 32,5 \\
\hline $\begin{array}{l}\text { Leaders - over } \\
10000 \text { ha }\end{array}$ & 2 & 1 & 14,3 & 5,0 & 11508,5 & 17792,0 & 40,0 & 32,2 \\
\hline Total & 14 & 20 & 100,0 & 100,0 & 57594,0 & 72766,8 & 100,0 & 100,0 \\
\hline
\end{tabular}

Source: Own elaboration.

During the study period, there was a break-up of the enterprises of Myrhorod district of Poltava oblast: 6 companies (30\%) of less than 1000 ha, have been formed cultivating $3,6 \%$ of the total farmland. This has happened due to the decrease from 7 to 3 companies ranging in size from 1000 to 3000 ha (a group of «followers»). A positive fact is increasing «average performers» by 2 enterprises, but it also happened only due to the break-up of the companies. There is a growing number of «sub leaders» to 5 companies, with increased land-use by an average of 4645,5 ha for a company. In addition, this group LLC «UkrLatAgro gradually begins to succeed (a branch of the agricultural holding with Latvian investments). Also, there is a process of concentration of farmland, which the «leader» - LLC 
«Agrotech-Garantiya» having concentrated to 16154 ha $(22,2 \%$ of total farmland) - implements. We believe that this is largely due to the «Agrarian technological company - A.T.C.» co-partnership from Zhytomyr. The latter is a vertically- integrated agricultural company, one of the largest companies producing cereals, oilseeds and potatoes (only in Zhytomyr oblast in 2013 rented 19,3 thousand. ha of land) (У Житомирській області більше половини родючих земель обробляють заїжджі інвестори [Електронний ресурс] - Режим доступу: http://www.zhitomir.info/news_124007.html)).

So, there is consolidation of agricultural enterprises, while the largest farms of Myrhorod district of Poltava oblast have concentrated farmland with an area of 16154 ha (LLC «Agrotech-Garantiya»), 6875 ha (LLC «UkrLatAgro»), 5809 ha (LLC «Savyntsi»), 4102,3 ha (LLC «Promin-Pryvat»). Of these, only the enterprises of corporation «Pryvat-Agro» are engaged in production of animal products.

Nevertheless, today it is very problematic to fully evaluate the total rented farmland areas of these structures, because the recognized statistics does not reflect many aspects of this phenomenon. In addition, non-transparent relations in the integration structures greatly complicate the possibility of any cooperation with the executive authorities and local self-government. Indeed, sometimes the heads of department of agricultural and industrial development of district state administrations do not even know the name of the main enterprise that has located an affiliated organization in Myrhorod district and rented farmland.

An inadequate information on the activities of agricultural enterprises that are the members of the agricultural holdings can be displayed, to some extent, in the form of a pyramid (example - subordination of agricultural enterprises of Myrhorod district, the members of the agricultural holding «Pryvat-Agro») (figure 2).

Even regardless of activities of agricultural holdings, we understand the direct link between the well-being of rural communities and the effective management of agricultural commodity producers. In this case, it is quite logical to expect the new job formation for local residents, an increase in budget revenue from tax payments, improvements in infrastructure for the rural areas. As the researcher S. Demianenko rightly pointed out, such expectations are based on the fact that «the founders of these companies are the residents of the village, and they and their family members take advantage of this infrastructure: means of communications, medical, cultural and educational institutions (children go to kindergarten and schools, cultural centers, libraries, etc.)» (Дем'яненко 2008, p. 12). Such «scheme» of expectations could be implemented on condition of management of typical agricultural enterprises - JLLC, farms and cooperatives. It would seem that on the condition of the activities of the agricultural holding, the well-being of rural areas should grow in proportionately with the large-scale use of farmland of these companies. 


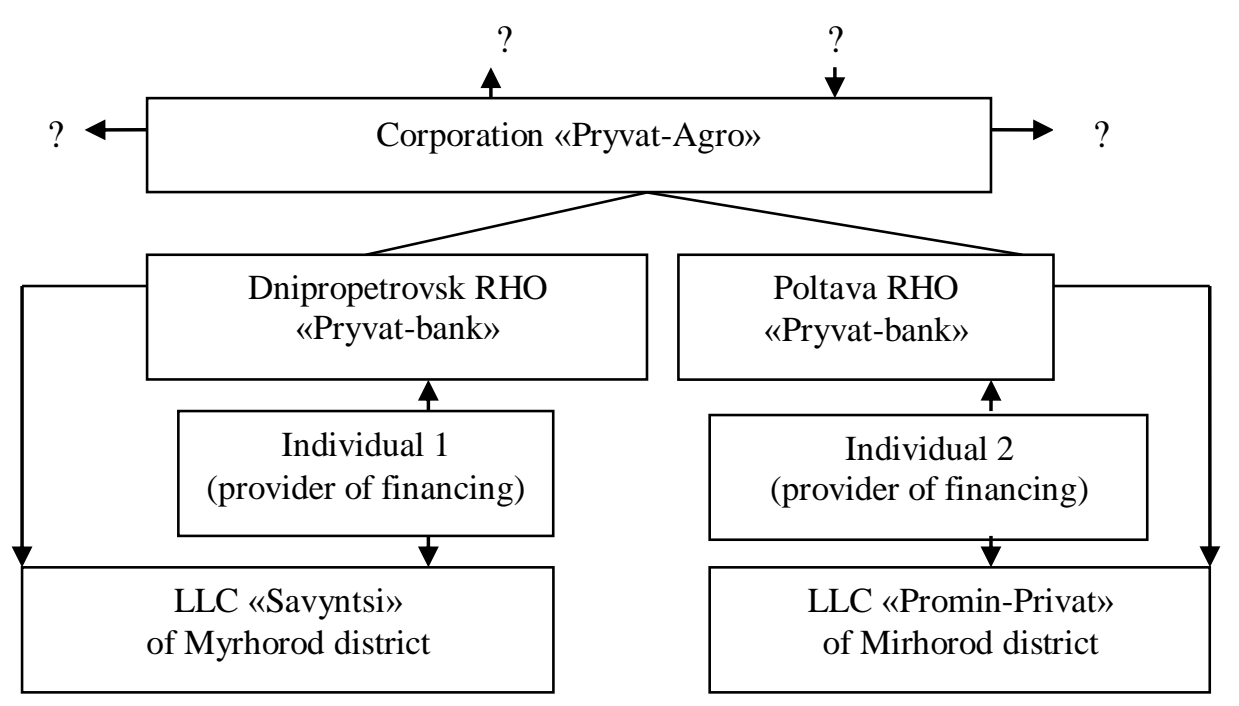

Figure 2. A fragment of a «pyramid» of subordination of agricultural enterprises as a part of the agricultural holding «Pryvat-Agro» [development of N. Demianenko]

Source: Own elaboration.

However, we can see a completely different picture. This is due to the lack of legal norm regarding all social duties of agricultural holdings to the community in rural areas. The founders of agricultural holdings often live in a completely different area, and neither they nor their family members use the rural infrastructure, this does not eventually promote the development of rural infrastructure, while some agricultural holdings are implementing the policy of social responsibility, have Regulations on Partnership, Social Programme, etc. Nevertheless, this is not typical for all these companies. In most cases, this is the PR-actions, and not of a systemic nature.

We can analyze the social and economic work of agricultural enterprises, which is typical for groups of the enterprises, divided according to the area of farmland (table 3).

Even not a deep analysis of the situation in agriculture in recent years of Ukraine shows that the majorities of small and medium-sized agricultural enterprises «continues to systematically show the unprofitablility and, therefore, are not able to support the village» (Шанін 2015, pp. 189-194). Therefore, table 3 confirms the scientific thought about small businesses that operate nonsystematically and are unprofitable.

Agricultural holdings get substantial profits, as they use low-paid work force, for example, the level of wages in the LLC «Promin-Pryvat» was the lowest - 2044,75 UAH per / month. To 1 ha to cultivate this enterprise they need 1 or 2 farm machinery operators. Companies of the agricultural holdings of Poltava oblast actively employ the students of Poltava State Agrarian Academy. The most popular specialties are an agronomist and a mechanical engineer. The increase of the number of young people is due to new and risky ideas of youth that promote agricultural development. 
Table 3. Economic efficiency and social community support by enterprises of Myrhorod district of Poltava oblast (depending on the area group), 2014

\begin{tabular}{|c|c|c|c|c|c|c|}
\hline $\begin{array}{c}\text { Groups of enterprises } \\
\text { of agricultural area } \\
\text { land, ha }\end{array}$ & 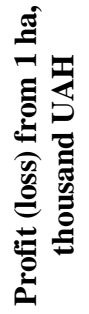 & 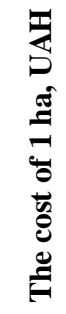 & 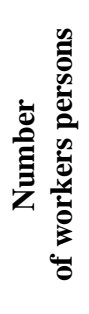 & 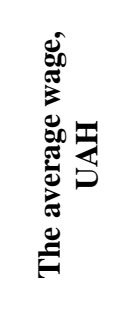 & 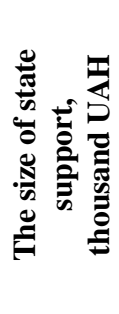 & 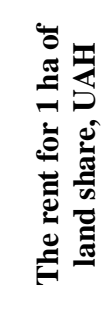 \\
\hline $\begin{array}{l}\text { Small performers (LLC } \\
\text { «Khorol-Don») }\end{array}$ & 0,5 & 8,2 & 47 & 2212,60 & 162,0 & 1098,6 \\
\hline $\begin{array}{l}\text { Followers (JLLC } \\
\text { «Slavutych») }\end{array}$ & 1,3 & 5,9 & 28 & 2505,95 & 665,0 & 1218,2 \\
\hline $\begin{array}{l}\text { Average performers } \\
(\text { LLC } \ll \text { Promin-Pryvat») }\end{array}$ & 6,8 & 1,1 & 162 & 2044,75 & 893,0 & 1134,9 \\
\hline $\begin{array}{l}\text { Sub-leaders (LLC } \\
\text { «UkrLatAgro»)* }\end{array}$ & 7,0 & 2,2 & 58 & 2401,23 & 120,6 & 1115,3 , \\
\hline $\begin{array}{l}\text { Leaders (LLC «Agrotech- } \\
\text { Garantiya») }\end{array}$ & 7,4 & 4,6 & 351 & 3210,00 & 0,0 & 1419,6 \\
\hline
\end{tabular}

* Members of the of agricultural holdings

Source: Own elaboration.

LLC «Promin-Pryvat» has the lowest rent for the land - 1134,9 UAH per 1 ha of land share. At the same time, in addition to substantial grants from the parent company «Pryvat-Agro» this company got 839 thousand UAH of state support.

In addition, these enterprises, which are the members of agricultural holdings, have a low level of production costs per 1 ha. This is a factor of profit growth because of using cheap resources and raw materials in the vertical and horizontal integration. We note, however, that in many agricultural holding companies (46\%) livestock forming is developing as a supporting industry to improve the productivity of grain farms (Кропивко, Лупенко 2013, pp. 5-21).

In addition, if at the time of the Soviet Union, rural social infrastructure was on the balance of state farms and collective farms, since the period of independence of Ukraine it has passed to the balance of rural (village) councils which now are not able to fund it at a proper level. Present agricultural enterprises do not direct their work to the development of rural areas, even getting profits. This is due to farmland fragmentation of agricultural holdings between rural councils. Furthermore, many companies are located at cities such as LLC «Agrotech-Garantiya» - in Myrgohod, the same tax liabilities are for the development of the city.

Social support of local communities is carried out periodically by agricultural enterprises, and not systematically. To determine the specific sums of the enterprises is impossible, since these expenses in the financial statements are presented as manufacturing. The reason for this approach is the high level of taxation on social spending of business. Imperfect tax legislation of Ukraine should be classified as factors that provide negative impact of agricultural holdings on the social and economic development of rural areas. 
Studying the impact of agricultural holdings on social and economic development of rural areas, the scientist V. Zalizko defines a number of negative consequences of this process (Залізко 2013, pp. 71-78). Negative consequences given by the researcher, both in the sphere of social relations, and in the sphere of ecological safety of the population, are directly related to the problem of the concentration of agricultural holdings of farmland. Thus, the negative social consequences of the activities of agricultural holdings in rural areas include the following:

- hyper-capitalization of land bank of agricultural holdings can lead to the fact that rural residents would lose control over most fertile farmland. Furthermore, there is a low percentage of landlords fees for the use of land shares;

- the growth of unemployment among the rural population due to the displacement of labor-intensive agricultural production, the transition to monoproduction and the usie non-diversified agricultural machinery.

It should be noted that agricultural holdings require highly skilled professionals for new foreign technology service. However, the available rural labour force in terms of the development of high technology and machinery does not meet these requirements. For the reason of economy, agricultural holdings are not going to finance the training of specialists of the rural sector at the place of the leased farmland, and employ workers from other districts who have received vocational training by their own or at state expense. Such approach, in practice, leads to higher unemployment in rural areas among residents with educational level, and among those who have received higher education and have a high skilled level.

Thus, in 2009 JSC «Scientific and Production Company «Harvest», that is a member of the vertically-integrated business PJSC «Myronivkyi Hliboproduct», leased the land with the area of 43 districts of 5 districts of Cherkasy and Kyiv oblasts. However, on the average five locals from the village were involved in production operations. It is quite clear that there is a need for state regulation of employment of working rural population in the areas of agricultural holdings. In addition, it would be wiser to provide the landlords with the right of high priority employment in the structure of the enterprise-renter.

The impoverishment of rural population, the development of migration and extinction of rural areas could lead, in the nearest future, to the fact that most rural areas simply become a base area for the increase of farmlands of agricultural holdings.

In addition, the trend towards concentration of agricultural holdings of farmland and their further ruthless exploitation has a negative environmental impact (Залізко 2013, pp. 71-78).

Negative impact, as determinated by scientists, of the activities of agricultural holdings on ecology is significantly strengthened by the fact that the residents of rural areas are alone in the struggle with the consequences of this influence. The budgets of the rural communities are not able to finance the environmental actions. In reality, the program at a districtal level will only be able to work on ther condition of appropriate funds from the government budget. 
Thoroughly analyzing the impact of agricultural holdings on agricultural development of Ukraine, S. Demianenko concludes: «It should be noted that some agricultural holdings are responsible for costs associated with social infrastructure support. However, due to the fact that agricultural holdings are located mainly in the cities, they almost do not pay taxes to the local budgets of rural areas. The former collective farms, which have lost the status of a legal identity, have become subsidiaries or divisions of agricultural holdings. This is often a disadvantage for rural areas. Therefore, it is necessary to introduce a mechanism that would ensure the payment of taxes by enterprises and organizations, where agribusiness is not located of the main company but of the location of their subdivisions, i.e., in the countryside. This allows the rural councils to accumulate funds of local budgets for the development of social infrastructure» (Дем'яненко 2008, p. 12).

Therefore, for the organization of co-operation of all agricultural enterprises (especially of agricultural holdings), bodies of local government and communities of villages and towns we offer to use a mechanism of interaction, that will function on the basis of partnership (figure 3 ).

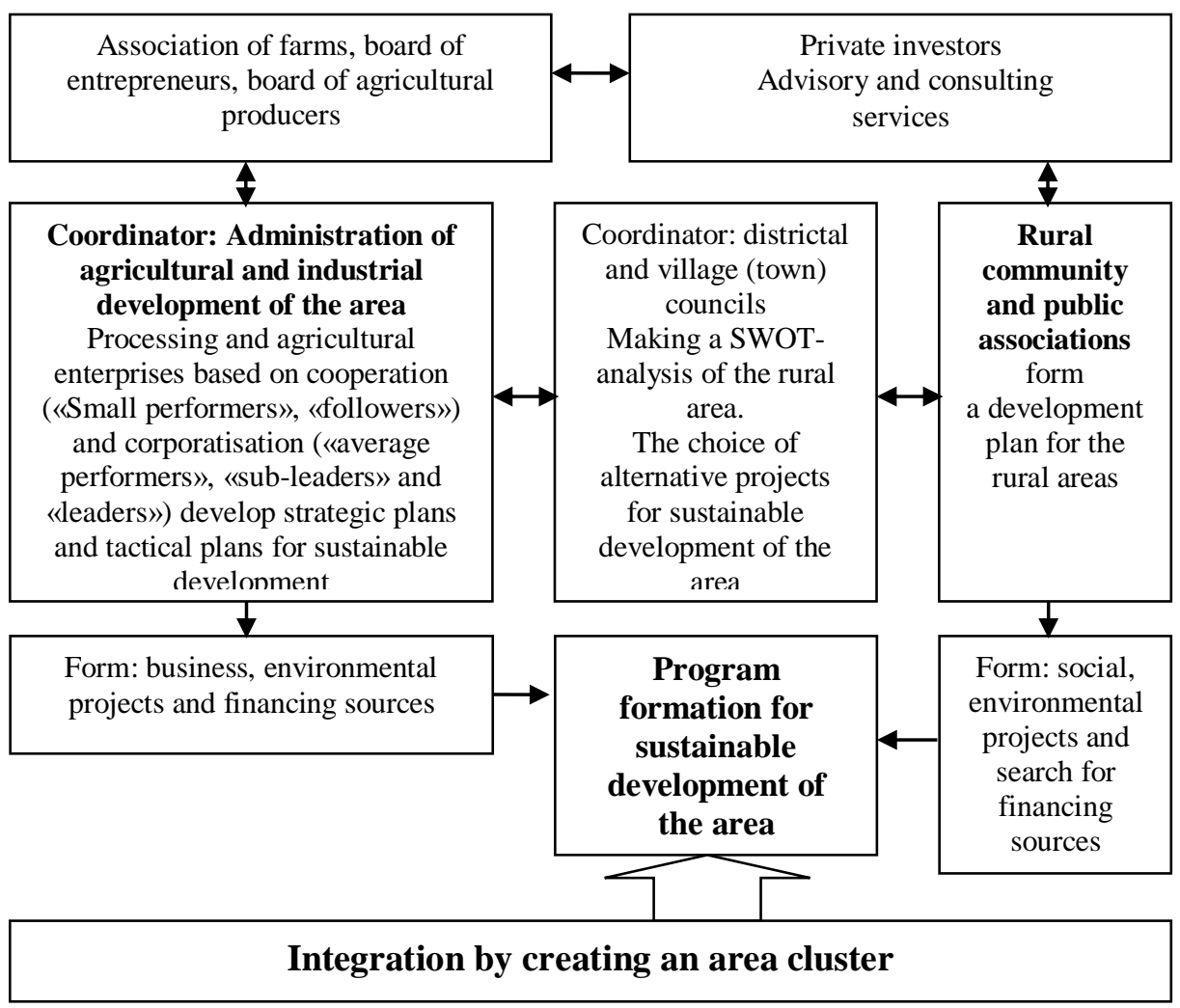

Figure 3. The model of strategic planning for the development of cooperative and corporative structures based on rural development [author model of N. Demianenko]

Source: Own elaboration. 
So, it is advisable for small producers to be integrated as cooperatives, and to make development business plans that will provide employment for rural population. Corporate formation (enterprises that are members of holding companies) should be directed to horizontal diversification. Moreover, due to increasing the profitability it is advisable for all businesses to allocate funds for social development of the projects of the community of villages and towns. An integrator two poles at the districtal level should be the districtal and village (town) councils. To encourage agricultural enterprises and investors' participation in the implementation of these projects, we offer for them to determine the obligations of state authorities to support the implementation.

Also, during the development of the economic strategies and programs of most small businesses («small performers», «followers»), we recommend to practice coupled specialization in the production of land-poor labor-intensive crop and livestock products, and to enter into a joint business activity, using the mechanism of cooperation and clustering based on social support of rural areas.

Moreover, we propose to agricultural holdings to develop environmentaloriented agricultural and industrial production, raise the level of social orientation of their activities and act as an integrator of joint economic activities, increase the level of social orientation of their work and act as integrators of joint economic activities. It is advisable to recommend the structures of agricultural holdings to create the department of information and social policy. This institution, in an integrated manner with local authorities and local territorial communities, based on conclusion of social responsibility agreement with the head of the village council, will provide solving the most important financial problems in the areas of education, medicine, spiritual dimension, landscape design of rural areas and so on. Such proposals must have a clear legislative consolidation that will allow to monitor the activities of agricultural holdings at the state level.

A detailed mechanism of co-financing of projects of sustainable rural development is shown in figure 4.

Thus, based on the proposed mechanism agricultural holdings together with other governmental and non-governmental organizations will fund rural development. Both the state budget (within the state development programs of agricultural and industrial production and rural areas) and local budgets can serve as the source of public funding of rural development.

Summarizing the presented material, for increasing social orientation of agricultural holdings we offer to implement the following measures:

1. Agricultural holdings should develop Programs of social investments aimed at financial support of the most important projects initiated by territorial communities.

2. Agricultural holdings should form the fund of sustainable development of rural areas, and provide funding for each hectare of leased land.

3. For the use of rural social infrastructure services (water, roads, electricity, etc.) we offer to the fund of social development of agricultural holdings to allocate funding to the territorial community fund annually. It is necessary to calculate the costs depending on the area of land leased by agricultural holding.

4. It is obligatory to work closely with agricultural universities and to establish joint training centers. 


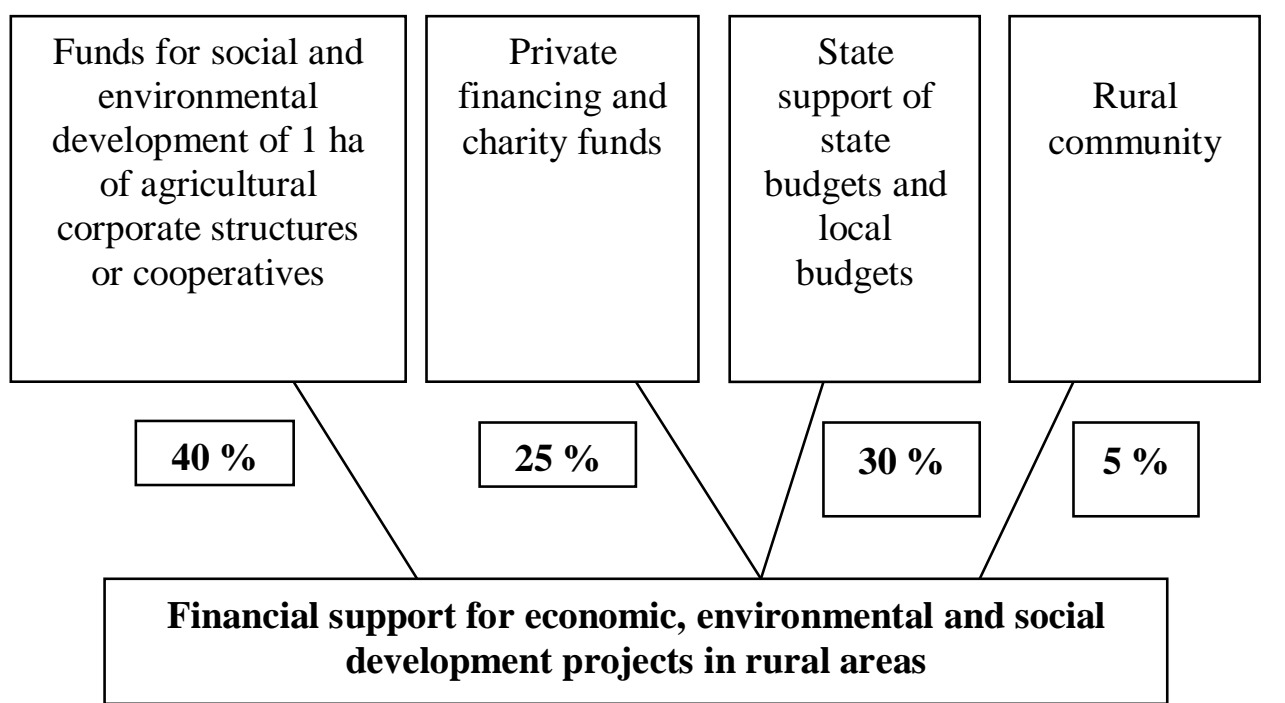

Figure 4. The mechanism of financial support for projects in rural areas [developed by the authors on the basis

Source: Обласна цільова програма впровадження в Полтавській області III фази Проекту Свропейського Союзу (ЄС) та Програми Розвитку Організації Об’єднаних Націй (ПРООН) «Місцевий розвиток, орієнтований на громаду» на 2015-2017 роки [Електронний ресурс] - Режим доступу: https://docviewer.yandex.ua

To attract young promising professionals into the agricultural production and support persons wishing to move to rural areas, it might be necessary to oblige agricultural holdings at the legislative level to create favorable conditions, first of all, to provide young families with housing accommodations.

\section{Conclusions}

The development of agricultural holdings in Ukraine as a whole, and the analysis of individual vertically-integrated agricultural enterprises of Myrhorod district of Poltava oblast have found their strong economic growth with a significant social and environmental decline of rural areas, within the enterprise economy.

Therefore, in future it is necessary to increase state control over the activities of agricultural holdings to involve them to the system-forming mechanism of a sustainable development of rural areas. It is necessary to introduce a mechanism that would ensure the flow of funds in the implementation of community projects in the places of activities of agricultural divisions of corporations. At the same time, as an alternative of further limit the land tenure of large corporate structures, the state should create the right conditions for the organization of cooperatives.

Thus, agricultural enterprises, which are members of agricultural holding companies, accumulating considerable resources of farmland, must develop and act only on the condition of sufficient level of social and economic life of rural areas. 


\section{References}

1. Brzozowska A., Kalinichenko A., Kabus J., Analyzing the strategies used in media discourse management, J. Eastern-European Journal of Enterprise Technologies, 2015, Vol. 5, Nr 3(77), pp. 10-14. DOI: 10.15587/1729-4061.2015.51397.

2. Ukrlandfarming. Publik Limited Company: Офіційний сайт [Електронний ресурс] Режим доступу: http://www.ulf.com.ua/ru.

3. Агропросперис (NSH) / Агропортал Latifundist.com [Електронний ресурс] - Режим доступу: http://latifundist.com/rating/top100/27938-new-century-holding

4. Воловик О.А., Щодо причин усталеності в Украӥні деяких архаїчних форм господарювання: інституиіональний підхід // Часопис Академії адвокатури України. 2012. - № 4, p. 4.

5. Дем'яненко С. І. Агрохолдинги в Украӥні: добре чи погано? Німеиько-украӥнський аграрний діалог [Електронний ресурс]. К.: Ін-т економ. дослід. та політич. консультацій, 2008, p. 12, Режим доступу: http://www. ier.com.ua/files/publications/Policy_papers /Agriculture_dialogue/ 2008/AgPP_21_Ukr.pdf.

6. Залізко В.Д. Вплив агрохолдингізаиії сільськогосподарських підприємств на соиіальноекономічний розвиток сільських територій // Економіка України. — 2013. — № 6. pp. 71-78.

7. Зарицька Н.П., Ретроспектива розвитку агрохолдингів в Україні крізь призму менеджменту // Розвиток агробізнесу в Україні: проблеми, пріоритети, перспективи: матеріали Всеукр. наук.-практ. конф., присвяченої 10-річчю факультету аграр. менеджменту (Україна, м.Житомир, 25-27 березня 2010 р.). - Житомир: Вид-во ЖДУ ім. І. Франка, 2010 р. 312.

8. Кропивко М. Ф., Лупенко Ю.О., Агрохолдинги в Україні та посилення соиіальної спрямованості їх діяльності // Економіка АПК. - 2013. - № 7, pp. 5-21.

9. Кулініч П., Ринок сільськогосподарських земель в Украӥні: чи зможе він функиіонувати на праві оренди [Електронний ресурс] // Юридичний журнал. - 2014. № 4. - Режим доступу: http://www.justinian.com.ua/article.php?id=4068

10. Найбільші агрохолдинги Украйни [Електронний ресурс]: веб-сайт агропорталу AgriSurver - Режим доступу: https://docviewer.yandex.ua.

11. Обласна иільова програма впровадження в Полтавській області ІІІ фази Проекту Свропейського Союзу (ЄС) та Програми Розвитку Організації Об'єднаних Націй $($ ПРООН) «Місцевий розвиток, орієнтований на громаду» на 2015-2017 роки [Електронний ресурс] - Режим доступу: https://docviewer.yandex.ua.

12. Ton 100 латифундистов Украины [Електронний ресурс]: веб-сайт агропорталу Latifundist.com - Режим доступу : http://latifundist.com.

13. У Житомирській області більше половини родючих земель обробляють зайжджі інвестори [Електронний ресурс] - Режим доступу: http://www.zhitomir.info/news_ 124007.html.

14. Уркевич В.Ю., Правові проблеми функиіонування агрохолдингів в Украӥні [Електронний pecypc]. - Режим доступу: http://ndipzir.org.ua/wp-content/uploads/2014/01/Urkevych.pdf.

15. Шанін О. В. Концепиія селоутворюючого підприємства в системі розвитку сільських територій // Ефективна економіка. - 2015. - № 4, pp. 189-194.

16. Шувар Б. І., Підгребельна М. І., Особливості діяльності великотоварних аграрних підприємств та їх вплив на аграрний ринок украӥни // Вісник аграрної науки Причорномор'я. - 2015. - Вип. 1, pp. 58-64. 


\section{WPEYW GOSPODARSTW ROLNYCH NA ROZWÓJ OBSZARÓW WIEJSKICH}

Streszczenie: Opracowanie podejmuje kwestię wpływu koncentracji gospodarstw rolnych na rozwój obszarów wiejskich. Analiza tego zagadnienia ujawniła szereg problemów natury społeczno-środowiskowej. Stała tendencja zwiększania koncentracji gospodarstw rolnych nie wywiera odpowiedniego, pozytywnego wpływu na rozwój obszarów wiejskich. Zauważono, że nie istnieją skuteczne mechanizmy wpływu na państwowe i samorządowe gospodarstwa rolne. Zbadano sytuację wzrostu powierzchni gruntów rolniczych gospodarstw $\mathrm{w}$ regionie myrhorodzkim w obwodzie połtawskim w obrębie poziomo zintegrowanych przedsiębiorstw. Zaproponowano mechanizm uczestnictwa gospodarstw rolnych w klastrze terytorialnym w celu nawiązania współpracy w zakresie realizacji projektów społecznych, ekonomicznych i środowiskowych. Udowodniono konieczność konsolidacji odpowiedzialności społecznej gospodarstw rolnych dla wsparcia społeczności wiejskich na poziomie legislacyjnym, w których przedsiębiorstwa wykorzystują grunty rolne dla swojej działalności.

Słowa kluczowe: gospodarstwa rolne, użytkowanie gruntów, koncentracja pól uprawnych, obszary wiejskie, zrównoważony rozwój, program rozwoju, infrastruktura społeczna, wsparcie społeczne 